\title{
Article \\ Felled and Lure Trap Trees with Uncut Branches Are Only Weakly Attractive to the Double-Spined Bark Beetle, Ips duplicatus
}

\author{
Vojtěch Šotola ${ }^{1}$, Jaroslav Holuša ${ }^{2, *} \mathbb{1}$, Karel Kuželka ${ }^{3} \mathbb{D}$ and Emanuel Kula ${ }^{1}$ \\ 1 Department of Forest Protection and Wildlife Management, Mendel University, Zemědělská 1665/1, \\ 61300 Brno, Czech Republic; vojtech.sotola@mendelu.cz (V.Š.); emanuel.kula@mendelu.cz (E.K.) \\ 2 Department of Forest Protection and Entomology, Czech University of Life Science, Kamýcká 129, \\ 16500 Praha-Suchdol, Czech Republic \\ 3 Department of Forest Management, Czech University of Life Science, Kamýcká 129, 16500 Praha-Suchdol, \\ Czech Republic; kuzelka@fld.czu.cz \\ * Correspondence: holusaj@seznam.cz; Tel.: +420-602-351908
}

check for updates

Citation: Šotola, V.; Holuša, J.;

Kuželka, K.; Kula, E. Felled and Lure Trap Trees with Uncut Branches Are Only Weakly Attractive to the Double-Spined Bark Beetle, Ips duplicatus. Forests 2021, 12, 941. https://doi.org/10.3390/f12070941

Academic Editor: Christian Hébert

Received: 25 May 2021

Accepted: 14 July 2021

Published: 17 July 2021

Publisher's Note: MDPI stays neutral with regard to jurisdictional claims in published maps and institutional affiliations.

Copyright: (c) 2021 by the authors. Licensee MDPI, Basel, Switzerland. This article is an open access article distributed under the terms and conditions of the Creative Commons Attribution (CC BY) license (https:/ / creativecommons.org/licenses/by/ $4.0 /)$.

\begin{abstract}
Bark beetles are the most important forest pests in the Northern Hemisphere. The range of Ips duplicatus, an invasive bark beetle in central Europe, has been steadily expanding, and it is now responsible for a high proportion of the spruce wood infested by bark beetles. Apart from searching for and eliminating infested trees, there is no effective control method. The aim of this study was to determine whether trap trees with a pheromone evaporator can be used to capture I. duplicatus. Felled trap trees with branches and with pheromone lures (ID Ecolure ${ }^{\circledR}$ ) were infested by I. duplicatus, at a median density of 1 nuptial chambers per $0.1 \mathrm{~m}^{2}$ (median); similar trees without lures and lying at a distance of 1,5 , or $10 \mathrm{~m}$ from the lure trees were rarely infested by I. duplicatus. The entire surface of the lure trees could capture $<400$ beetles per tree. The results indicate that lure trap trees (felled and with branches attached) could only be used in a limited number of situations; one such situation would involve forests that suffered wind damage and contained very high numbers of I. duplicatus.
\end{abstract}

Keywords: control; E-myrcenol; ipsdienol; Ips duplicatus; Ips typographus; pheromone; spruce

\section{Introduction}

The double-spined bark beetle Ips duplicatus (Sahlberg, 1836) (Coleoptera, Curculionidae, Scolytinae) is native to Fennoscandia, Siberia, and East Asia [1]. During the 20th century, I. duplicatus spread south to Central Europe because of the increased transport of wood that had not been debarked [2-4]. The distribution of I. duplicatus has continued to steadily expand [5], and in places where it has been established for a long time, its population densities have increased. Since the 1990s in Poland, the Czech Republic, Slovakia, and Romania, I. duplicatus has infested high volumes of spruce wood [6-10].

The most effective way to control bark beetles that attack spruce trees is to remove infested trees from the forest before the new generation of adult beetles emerges [11]. Supporting control measures include the deployment of trap trees. Such trees, which are used to capture the spruce bark beetle Ips typographus (Linnaeus, 1758) in many countries [12], are mostly felled trees whose branches have been detached and placed over the trunk [13]. I. duplicatus, however, does not infest fallen trees or trap trees whose branches have been detached, and therefore such trees cannot be used for its efficient detection and control $[6,14,15]$. Because the biology and ecology of I. duplicatus is poorly understood, the reason why beetles do not attack lying trees is not known.

In some regions, branches have only recently been left attached to trap trees for the control of I. typographus [16]. Crown branches prevent the trunk from falling to the ground and cause substantial water loss from the trunk because the needles attached to the crown branches transpire water for some time. The branch-covered trunk is much more attractive 
to I. typographus than the trunk with attached branches [17-21]. Advantages of leaving branches attached are (1) the trees can be felled later; and (2) I. typographus fly to trunks with attached branches earlier than to trunks with detached branches [22,23]. Stem occupancy by I. typographus differs in trap trees with and without attached branches. I. typographus prefers to infest the crown of trap trees with attached branches but also prefers to infest the trunk of trap trees without attached branches [21].

In some localities, trap trees with attached branches can at least partially attract $I$. duplicatus [24]. It is possible that a trap tree with branches may attract I. duplicatus due to the intense release of volatiles from needles and branches; I. duplicatus beetles use both natural pheromones and specific host volatiles as olfactory stimuli to locate breeding material [9]. The addition of artificial pheromone lures, of which there are several types that differ in efficiency [25], could increase the infestation of trap trees by the first males.

As previously observed [26], the addition of a pheromone evaporator should increase the attractiveness of trap trees with branches, and the combination of trap trees with branches plus pheromone lures could be useful for I. duplicatus control. This would be appreciated by forest managers because they would save money by not cutting the branches; the trunks with branches attached would be processed by harvesters after $I$. duplicatus infestation but before the next generation emerged. This would be especially advantageous during I. duplicatus outbreaks when an enormous number of trap trees are deployed, e.g., >5 million per year in the Czech Republic [27-29].

The aim of this study was to assess the level of I. duplicatus infestation in felled trap trees with branches left attached and with and without pheromone lures.

\section{Materials and Methods}

\subsection{Species Studied}

Ips duplicatus prefers spruce that are $>40$ years old and that are growing in non-native habitats $[4,6,7,30]$. Ips duplicatus can co-occur with other bark beetle species, and these are mainly I. typographus, Ips amitinus (Eichhoff, 1871), and Pityogenes chalcographus (Linnaeus, 1761 ) in forests that are $>60$ years old. However, I. typographus and I. amitinus may be competitors of I. duplicatus $[15,31,32]$.

Ips duplicatus adults emerge from the duff of the forest floor on warm spring days and fly to host trees that are stressed. The males are responsible for host tree selection. The females are attracted by male pheromones, which contain ipsdienol and E-myrcenol [33,34]. The pheromones attract both sexes. Several females join each male in his nuptial chamber [35].

Each female bores a maternal gallery and lays an average of 60 eggs in niches on both sides of the gallery. After approximately 1 to 2 weeks, the larvae hatch and begin to bore galleries that are approximately $5 \mathrm{~cm}$ long. The larval stage usually lasts 2 to 4 weeks, depending on temperatures. Pupation takes about 1 week, and the beetles require additional feeding time for maturation. Maturation feeding requires about 2 weeks, after which the beetles are ready to produce a new brood. The development of one generation usually takes 6 to 8 weeks in Central Europe. The beetles can establish sister generations after the establishment of the main generations. Ips duplicatus produces two or three generations per year, and the main peaks of beetle emergence in central Europe occur in April/May, July, and August/September [14,35,36].

\subsection{Study Area}

The trap trees were deployed in the hills (400-600 m asl) of the eastern Czech Republic in 2016-2018 (Table 1). In this area, I. duplicatus numbers have been increasing for a long time [8].

The I. duplicatus population had reached an outbreak level in the studied area. In 2016 and 2017, the volume of spruce wood infested by I. typographus, I. duplicatus, and other less numerous species ranged from 0.5 to $1.0 \mathrm{~m}^{3}$ per ha of spruce forests; in 2018, this value exceeded $10 \mathrm{~m}^{3}$. The population of I. duplicatus has been outbreaking in the studied 
area for long time. In 2005, the numbers of beetles of I. duplicatus captured in Theysohn ${ }^{\circledR}$ pheromone traps lured with ID Ecolure ${ }^{\circledR}$ had already exceeded 1000 beetles per trap, i.e., these had already attained an outbreak population density [8]. The numbers reached almost 2000 in 2016 and 5000 beetles in 2018. In 2017, captures exceeded 5000 beetles in forest districts [27-29].

Table 1. Characteristics of studied localities.

\begin{tabular}{|c|c|c|c|c|c|c|c|}
\hline Location & $\begin{array}{c}\text { Latitude }\left({ }^{\circ}\right) ; \\
\text { Longitude }\left({ }^{\circ}\right)\end{array}$ & $\begin{array}{l}\text { Year of } \\
\text { Study }\end{array}$ & $\begin{array}{l}\text { Altitude } \\
\text { (m asl) }\end{array}$ & $\begin{array}{l}\text { Age of } \\
\text { Spruce } \\
\text { Forest }\end{array}$ & $\begin{array}{c}\text { Proportion of } \\
\text { Spruce }(\%)\end{array}$ & $\begin{array}{c}\text { Mean DBH } \\
(\mathrm{cm})\end{array}$ & $\begin{array}{l}\text { Stock Volume } \\
\qquad\left(\mathrm{m}^{3} / \mathrm{ha}\right)\end{array}$ \\
\hline Dvorce & $\begin{array}{l}49.8339 \\
17.5956\end{array}$ & 2016 & 610 & 60 & 83 & 28 & 317 \\
\hline Guntramovice & $\begin{array}{l}\text { 49.7824; } \\
17.5536\end{array}$ & 2017 & 710 & 60 & 65 & 29 & 264 \\
\hline Svatý Kopeček & $\begin{array}{l}\text { 49.6392; } \\
17.3431\end{array}$ & 2018 & 420 & 60 & 75 & 29 & 301 \\
\hline
\end{tabular}

\subsection{Sampling}

Five study plots were designated at each of the three localities. Study plots at each locality were separated by $\geq 100 \mathrm{~m}$. Each study plot contained one group of four felled spruce trees with branches; the trees were located in front of forest stand walls that were 60-70 years old and that faced south or west. In each plot and perpendicular to the direction of the forest stand wall, trees with a similar diameter and with a height of 20-24 m were felled either in a north/south or an east/west direction. The mean height of the bottom of the crown was $15.5 \pm 1.5 \mathrm{~m}( \pm \mathrm{SD})$. The mean diameter at breast height was $28.2 \pm 4.9 \mathrm{~cm}$ $( \pm \mathrm{SD})$. The surface area of the trunks was ca. $9 \mathrm{~m}^{2}$ per trap tree.

For each study plot, a central tree (the "lure" tree) was provided with a pheromone bait to attract I. duplicatus. The bait was ID Ecolure ${ }^{\circledR}$ (produced by Fytofarm, s.r.o., and containing ipsdienol 1.6\%, myrcenol, spruce resin and ethanol), which is the most effective lure [25]. The bait was placed on the first whorl of green branches of the crown on 25 April of each of the 3 years, which was immediately before the beginning of the flight activity of I. duplicatus. The three other trap trees were placed at 1,5, and $10 \mathrm{~m}$ away from the tree with the lure. The sides alternated, so that at two study plots, the trap trees without lures were located north or west of the trees with lures, and at three study plots, the traps trees were located to the south or east of the trees with lures.

As a consequence, there were four types of trap trees: trap trees with lures and trap trees without lures that were 1,5 , or $10 \mathrm{~m}$ away from trap trees with lures.

Infestation of trap trees by I. duplicatus was assessed in mid-June, when the first pupae were detected under the bark. The number of nuptial chambers and the number of maternal galleries of all bark beetle species were recorded on debarked, consecutive bark strips $(10 \mathrm{~cm} \times 1 \mathrm{~m})$ on the upper side of the trunk. The consecutive bark strips cover the entire bole of the tree. Strips that were $10 \mathrm{~cm}$-wide were used because a $10 \mathrm{~cm}$-wide strip represented the entire surface of the trunk on the thinnest part of the trees.

\subsection{Data Analyses}

Statistical analysis was performed with MATLAB R2021a (The MathWorks Inc., Natick, MA, USA). Numbers of nuptial chambers per $0.1 \mathrm{~m}^{2}$ and maternal galleries per $1 \mathrm{dm}^{2}$ were used as response variables, and trap tree type, year, position of strip on trap tree (height), and plot (plot) were used as the explanatory variables. There were four types of trap trees: trap trees with lures and trap trees without lures that were 1,5, or $10 \mathrm{~m}$ away from trap trees with lures. Because the response variable followed a Poisson distribution, a general linear regression model in the form $\log$ (numbers of nuptial chambers) $\sim 1+$ plot + type + height (Poisson distribution of response variable) was used to quantify the effect of the predictors on the number of nuptial chambers for each bark beetle species. To quantify 
the effect of the predictors on the number of maternal galleries, the form of the generalized linear model was 1/(maternal gallery) $~ 1+$ plot + type + height, corresponding to the Gamma distribution of the response variable. For both models, link functions were chosen as the default link functions according to the distributions of the response variable. When calculating the effect of year on numbers of nuptial chambers and maternal galleries, year was used instead of plot. Although the position on trap tree trunks (height) was used as a predictor, the preferences of individual bark beetle species for positions on tree trunks are known [37]; as a result, we did not present the effects of this predictor.

\section{Results}

Numbers of I. duplicatus nuptial chambers on individual bark strips ranged from 0 to 9 per $0.1 \mathrm{~m}^{-2}$ with a median of 1.0. Numbers of I. typographus and P. chalcographus nuptial chambers ranged from 0 to 10 per $0.1 \mathrm{~m}^{-2}$ (Figure 1). The maximum number of maternal galleries per $\mathrm{dm}^{-2}$ of bark was 4, 5, and 6 for I. typographus, I. duplicatus, and $P$. chalcographus, respectively (Figure 2).

Numbers of I. typographus and P. chalcographus nuptial chambers, and maternal galleries of I. duplicatus did not significantly differ on lure trees vs. trees without lures that were 1,5 , or $10 \mathrm{~m}$ away from lure trees (Tables 2 and 3). For I. duplicatus, in contrast, the numbers of nuptial chambers were highest on the lure trees and significantly decreased with distance from the lure tree; as low numbers were detected on trees without lures that were $1 \mathrm{~m}$ away from lure trees, but none was detected on trees without lures that were 5 or $10 \mathrm{~m}$ away from lure trees (Table 2).

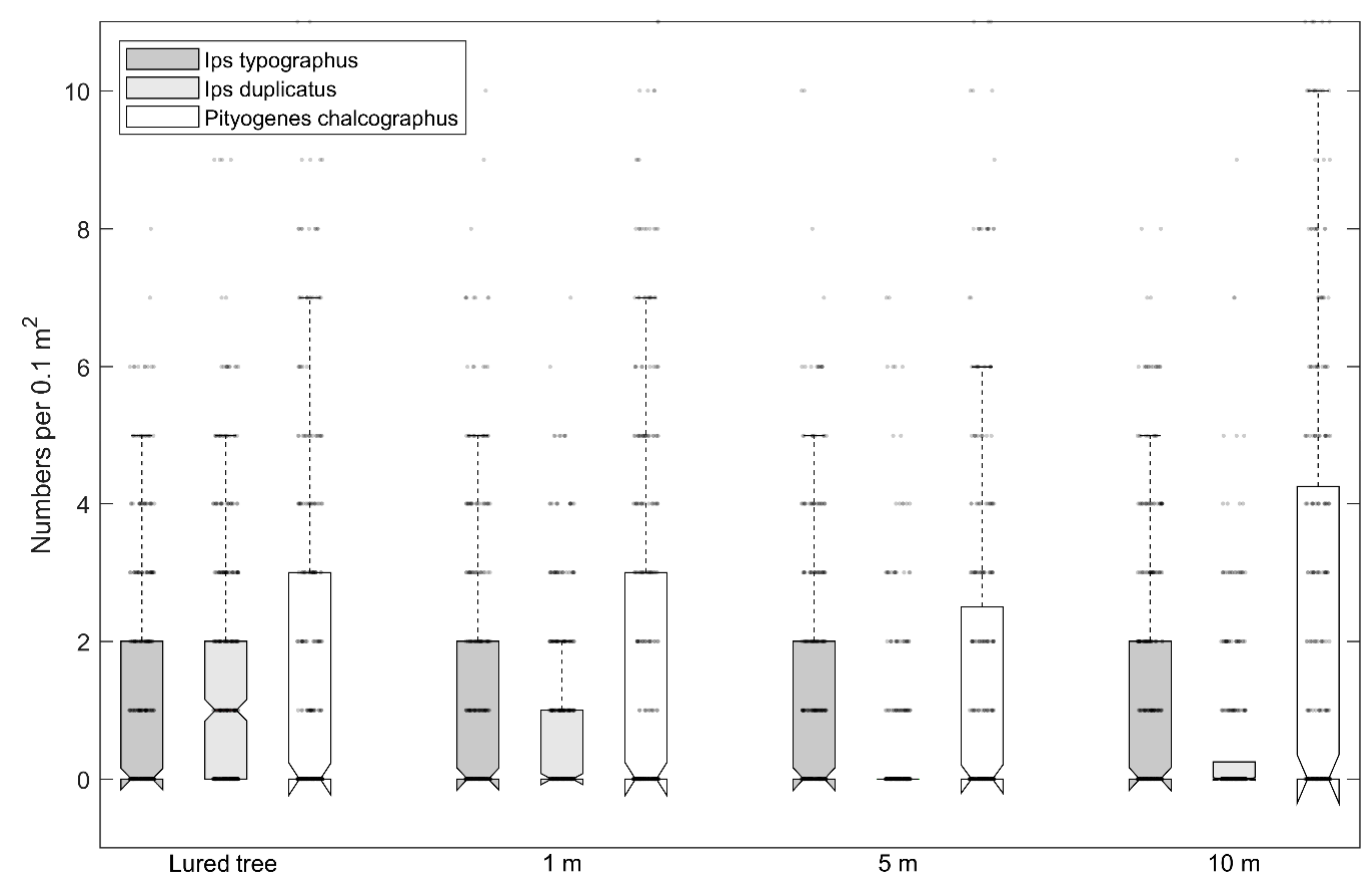

Figure 1. Number of Ips typographus, Ips duplicatus, and Pityogenes chalcographus nuptial chambers on felled trap trees with branches that had pheromone lures or that lacked pheromone lures; trees without lures were placed at 1,5 , or $10 \mathrm{~m}$ away from lure trees (notch-median; box plot-25\% and $75 \%$ values; dotted line-minimum-maximum without extremes; circles-values). The notch depth represents the confidence interval. 


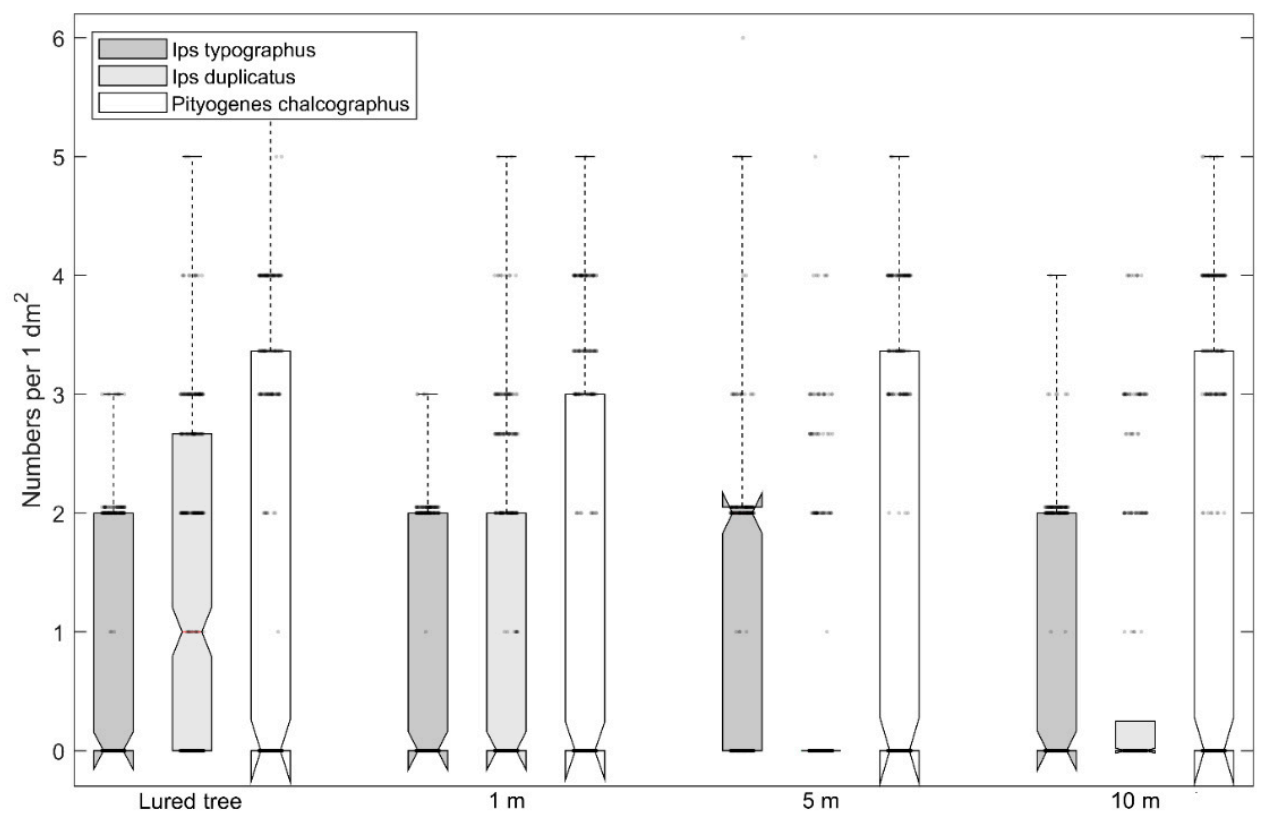

Figure 2. Numbers of Ips typographus, Ips duplicatus, and Pityogenes chalcographus maternal galleries on felled trap trees with branches and that had pheromone lures or that lacked pheromone lures; trees without lures were placed 1, 5, or 10 m away from lure trees (notch-median; box plot-25\% and 75\% values; dotted line: minimum-maximum without extremes; circles: values). The notch depth represents the confidence interval.

Numbers of I. duplicatus nuptial chambers and maternal galleries were highest in 2017, intermediate in 2016, and lowest in 2018. Numbers of P. chalcographus nuptial chambers and maternal galleries increased with year. Numbers of $I$. typographus nuptial chambers and maternal galleries were highest in 2017, were intermediate in 2016, and were lowest in 2018 (Appendices A and B).

Table 2. Relationships between the number of nuptial chambers and plot, type of trees (distance from lure tree), and the height of the position of strip on the trap tree as indicated by the general linear model $\log$ (numbers of nuptial chambers) $=1+$ plot + type + height. The coefficient estimates are accompanied with the standard error of estimate (SE) and the $p$-values.

\begin{tabular}{ccccc}
\hline Species & Type & Estimate & SE & $p$-Value \\
\hline Ips typographus & (Intercept) & -0.921 & 0.173 & $1.1 \times 10^{-7}$ \\
& 1 & 0.028 & 0.066 & 0.66 \\
& 5 & -0.053 & 0.066 & 0.42 \\
& 10 & 0.098 & 0.065 & 0.13 \\
\hline Ips duplicatus & (Intercept) & 1.120 & 0.133 & $3.43 \times 10^{-17}$ \\
& 1 & -0.539 & 0.070 & $8.86 \times 10^{-15}$ \\
& 5 & -0.860 & 0.085 & $3.95 \times 10^{-24}$ \\
& 10 & -0.867 & 0.083 & $1.52 \times 10^{-25}$ \\
\hline Pityogenes chalcographus & (Intercept) & -0.817 & 0.186 & $1.08 \times 10^{-5}$ \\
& 1 & 0.024 & 0.054 & 0.65 \\
& 5 & -0.070 & 0.055 & 0.21 \\
& 10 & 0.433 & 0.049 & $2.00 \times 10^{-18}$ \\
\hline
\end{tabular}


Table 3. Relationships between the number of maternal galleries and plot, type of trees (distance from lure tree), and height of position of strip on trap tree as indicated by the general linear model $1 /$ (maternal gallery) $\sim 1+$ plot + type + height. The coefficient estimates are accompanied with the standard error of estimate (SE) and the $p$-values.

\begin{tabular}{ccccc}
\hline Species & Term & Estimate & SE & $p$-Value \\
\hline Ips typographus & (Intercept) & 1.864 & 0.644 & 0.004 \\
& 1 & 0.054 & 0.242 & 0.82 \\
& 5 & -0.344 & 0.184 & 0.061 \\
Ips duplicatus & 10 & -0.081 & 0.225 & 0.72 \\
\hline & (Intercept) & 0.425 & 0.305 & 0.16 \\
\hline Pityogenes chalcographus & 1 & 0.102 & 0.112 & 0.36 \\
& 5 & 0.501 & 0.224 & 0.026 \\
& 10 & 0.413 & 0.194 & 0.034 \\
\hline & 1 & 2.159 & 0.374 & $9.3 \times 10^{-9}$ \\
& 5 & 0.038 & 0.074 & 0.61 \\
\end{tabular}

\section{Discussion}

Only three species of bark beetles (Ips typographus, Ips duplicatus, and Pityogenes chalcographus) were found on the felled trap trees in the current study. This was not surprising because these three species are the most numerous bark beetles in the study area $[13,38]$ and because these abundant species rapidly infest felled trees and thereby out-compete other species that might infest spruce. The infestation level of the trap trees varied from year to year, and this yearly variation was consistent with the abundance of the species in the wider area. For example, I. duplicatus was the most abundant species on our trap trees in 2017, which was the year when the largest number of I. duplicatus beetles were captured in pheromone traps that were deployed in the surrounding districts [27-29].

Among the four kinds of trap trees (lure and the trap trees without lures located at 1 , 5 , or $10 \mathrm{~m}$ distances from the lure trees), Ips duplicatus numbers were highest in the lure trap trees, and numbers among trap trees without lures declined with the distance from the lure trap trees. I. duplicatus attraction to the lure was probably also evident on the trap trees without lures located at a $1 \mathrm{~m}$ distance from the lure trees; researchers previously reported that the release of high concentrations of pheromones from one tree can cause $I$. duplicatus adults to also infest neighboring trees [31]. The failure of I. duplicatus to infest trap trees without lures located 5 or $10 \mathrm{~m}$ from lure trap trees confirms the well-known fact that I. duplicatus beetles attack standing trees only $[6,15]$.

Conifer bark beetles are guided by a combination of both positive cues (aggregation pheromones, host foliage monoterpene hydrocarbons, and microbial volatiles) and negative cues (heterospecific pheromones, non-host volatiles, and microbial volatiles) [39-44]. Aggregation pheromones play an important role in coordinating the insect attacks on the host trees [45-47], whereas the beetles use the intensity and spectrum of volatiles emitted by trees (e.g., terpenes and alcohols) to identify those trees that are most suitable for colonization [48-50].

It is very likely that host volatiles function as olfactory stimuli that attract I. duplicatus. This is supported by the tendency of I. duplicatus beetles, regardless of sex, to aggregate in areas where large amounts of fresh material are available [9] and to be attracted to $\alpha$-pinene [51].

Because the height of the dispersal flight of I. duplicatus generally corresponds to the height of the branches of the standing trees [52], this species is probably attracted by crown volatiles. Volatiles from spruce needles, knots, and wood extracts include characteristic compounds [53-56]. I. typographus, in contrast, mainly infests the subcrown parts of spruce trees because those parts emit the highest concentrations of monoterpenes $[49,57]$. Felled trees with branches attached can be especially attractive because the dying branches and 
needles may release abundant volatiles. The low emission of volatiles by trap trees whose branches have been removed would explain why these kinds of trap trees tend not to be infested by I. duplicatus, even when they were lured by a pheromone evaporator (Holuša, Galko observ.).

The release of volatiles varies greatly among trees and depends on temperature, light, and humidity $[44,58,59]$. This could help explain why $>1.5$ I. duplicatus nuptial chambers per $\mathrm{dm}^{-2}$ were observed on several lure trees in a previous study [26].

Ips duplicatus probably prefers standing trees for another reason. The essential pheromones are ipsdienol (Id) and E-myrcenol (EM) for I. duplicatus but are 2-methyl3-buten-3-01 (MB) and cis-verbenol (cV) for I. typographus [60]. In trees at an advanced stage of attack, after female egg deposition, I. typographus males produce ipsdienol (R-(-)) and ipsenol (R-(+)) in their hindguts [61,62]. Ipsdienol is attractive to females $[63,64]$ at low doses but repels females at higher doses [65]. Because the enantiomer ratio of ipsdienol is much higher in I. typographus than in I. duplicatus, I. duplicatus is unlikely to respond to the enantiomer ratio of ipsdienol in I. typographus. In a tree colonization model, the response of the two competing species to their respective pheromones shows a good separation during the mass attack, but a small initial cross-attraction [60]. It could benefit I. duplicatus to receive a cue indicating that the tree has been successfully attacked or weakened by I. typographus [60]. We therefore conclude that I. duplicatus is attracted to standing trees whose defenses have already been overcome by $I$. typographus. The two species apparently reduce their interspecific competition by infesting different parts of weakened trees; $I$. duplicatus prefers the crown, and I. typographus prefers the subcrown. On the other hand, we must admit that very abundant populations of I. duplicatus can occupy entire spruces, at least those weakened by drought. This happens especially in the case of smaller trees unsuitable for I. typographus (Holuša, observ.).

\section{Conclusions}

We found that felled spruces with branches and with pheromone lures (ID Ecolure ${ }^{\circledR}$ ) were only weakly infested with I. duplicatus. We suspect that this low level of infestation may have been due to the absence of both needle volatiles and an aggregation pheromone, two scents that were probably supplied by standing ring-barked lured trap trees. In addition, lures in our experiments were placed at a practical but low height of $3 \mathrm{~m}$. Our observations suggest that $I$. duplicatus is not attracted to lures placed at low heights (Holuša unpubl.). In the current study, based on the number of nuptial chambers (one per $0.1 \mathrm{~m}^{2}$ ) and sex ratio (1 male: 2.5 females) on the whole surface of the studied trees, we captured fewer than 400 beetles per whole lure tree. Although the number of I. typographus beetles is sufficient to overcome a weakened spruce tree [66], it is far lower than the number of $I$. duplicatus captured per monitoring trap previously reported in the study region [27-29]. This shows that pheromone traps are more efficient than trap trees for capturing I. duplicatus beetles. Unfortunately, captured beetles in pheromone traps must be removed regularly, because the smell from the accumulated dead beetles significantly reduces trapping efficacy [67].

Felled and lure trap trees with branches could be effectively used in only a limited number of situations; for example, they could be used in areas with substantial wind damage and with very high levels of I. duplicatus. If forest managers do not manage to process all of the trees in a wind-damaged area, we recommend the placing of pheromone traps at intervals of approximately 5-10 $\mathrm{m}$ to attract and capture at least part of the $I$. duplicatus population.

Author Contributions: Conceptualization, V.Š. and J.H.; methodology, V.Š.; formal analysis, K.K.; investigation, V.Š.; writing—original draft preparation, V.Š. and J.H.; writing—review and editing, V.Š. and J.H.; supervision, E.K. All authors have read and agreed to the published version of the manuscript. 
Funding: This research was funded by Ministry of Agriculture of the Czech Republic, grant number "QK 1920433-Influence of protective measures to populations bark beetles according on population density".

Institutional Review Board Statement: Not applicable.

Informed Consent Statement: Not applicable.

Data Availability Statement: The data presented in this study are available on request from the corresponding author.

Acknowledgments: The authors thank the foresters from the Lesy České Republiky, s.p. (state enterprise) for cooperation in the research.

Conflicts of Interest: The authors declare no conflict of interest.

\section{Appendix A}

Table A1. Relationships between number of nuptial chambers and year, type of plot (distance from lure tree), and tree height of position of strip on trap tree as indicated by the general linear model log (number of nuptial chambers) $=1+$ year + type + height. The coefficient estimates are accompanied with the standard error of estimate (SE) and the $p$-values.

\begin{tabular}{ccccc}
\hline Species & Year & Estimate & SE & $p$-Value \\
\hline Ips typographus & (Intercept) & 0.226 & 0.075 & 0.0028 \\
& 2017 & -2.253 & 0.120 & $1.38 \times 10^{-78}$ \\
& 2018 & 0.775 & 0.056 & $3.08 \times 10^{-44}$ \\
\hline Ips duplicatus & (Intercept) & 0.864 & 0.087 & $3.32 \times 10^{-23}$ \\
& 2017 & 0.851 & 0.077 & $1.29 \times 10^{-28}$ \\
& 2018 & -0.890 & 0.113 & $3.74 \times 10^{-15}$ \\
\hline Pityogenes chalcographus & (Intercept) & 0.570 & 0.064 & $8.53 \times 10^{-19}$ \\
& 2017 & 0.327 & 0.055 & $2.71 \times 10^{-9}$ \\
& 2018 & 0.686 & 0.054 & $5.25 \times 10^{-37}$ \\
\hline
\end{tabular}

\section{Appendix B}

Table A2. Relationships between number of maternal galleries and year, type of plot (distance from lure tree), and tree height of position of strip on trap tree as indicated by the general linear model $1 /$ (number of maternal galleries) $=1+$ year + type + height. The coefficient estimates are accompanied with the standard error of estimate (SE) and the $p$-values.

\begin{tabular}{ccccc}
\hline Species & Year & Estimate & SE & $p$-Value \\
\hline Ips typographus & (Intercept) & 1.199 & 0.176 & $1.51 \times 10^{-11}$ \\
& 2017 & 0.650 & 0.183 & 0.00041 \\
& 2018 & -0.338 & 0.124 & 0.0065 \\
\hline Ips duplicatus & (Intercept) & 0.609 & 0.169 & 0.00034 \\
& 2017 & -0.560 & 0.159 & 0.00043 \\
& 2018 & 3.267 & 0.468 & $4.41 \times 10^{-12}$ \\
\hline Pityogenes chalcographus & (Intercept) & 0.592 & 0.076 & $1.35 \times 10^{-14}$ \\
& 2017 & -0.146 & 0.063 & 0.020 \\
& 2018 & -0.052 & 0.068 & 0.448 \\
\hline
\end{tabular}

\section{References}

1. Pfeffer, A. Zentral-und Westpaläarktische Borken-und Kernkäfer (Coleoptera: Scolytidae, Platypodidae); Pro Entomologia, Naturhistorisches Museum: Basel, Switzerland, 1995; p. 310.

2. Piel, F.B.; Grégoire, J.C.; Knížek, M. New occurrence of Ips duplicatus Sahlberg in Herstal (Liege, Belgium). Bull. OEPP/EPPO Bull. 2006, 36, 529-530. [CrossRef]

3. Petercord, R.; Lemme, H. Der Nordische Fichtenborkenkäfer. LWF-aktuell 2019, 120, 48-50. 
4. Duduman, M.L.; Isaia, G.; Olenici, N. Ips duplicatus (Coleoptera: Curculionidae, Scolytinae) distribution in Romania. Preliminary results. In Bulletin of the Transilvania University of Brasov; Series II; Transilvania University Press: Brasov, Romania, 2011; Volume 53, pp. 19-27.

5. Wermelinger, B.; Mathis, D.S.; Knizek, M.; Forster, B. Tracking the spread of the northern bark beetle (Ips duplicatus [Sahlb]) in Europe and first records from Switzerland and Liechtenstein. Alp. Entomol. 2020, 4, 179-184. [CrossRef]

6. Grodzki, W. Zasieg wystepowania kornika zroslozebnego Ips duplicatus C.R. Sahlberg (Coleoptera: Scolytidae) w obszarach górskich poludniowej Polski. Sylwan 2003, 8, 29-36.

7. Olenici, N.; Duduman, M.L.; Tulbure, C.; Rotariu, C. Ips duplicatus (Coleoptera, Curculionidae, Scolytinae)—An important insect pest of Norway spruce planted outsider its natural range. Revis. Pädur. 2009, 124, 17-23.

8. Holusa, J.; Lubojacký, J.; Knížek, M. Distribution of the double-spined spruce bark beetle Ips duplicatus in the Czech Republic: Spreading in 1997-2009. Phytoparasitica 2010, 38, 435-443. [CrossRef]

9. Duduman, M.L.; Vasian, I. Effects of volatile emissions of Picea abies fresh debris on Ips duplicatus response to characteristic synthetic pheromone. Not. Bot. Horti Agrobot. Cluj-Napoca 2020, 40, 308-313. [CrossRef]

10. Vakula, J.; Galko, J.; Gubka, A.; Kunca, A.; Zúbrik, M.; Nikolov, C.H.; Rell, S. Výsledky monitoringu lykožrúta severského (Ips duplicatus) v roku 2016. In Proceedings of the 26th International Conference, Národné lesnícke centrum-Lesnícky výskumný ústav Zvolen, Nový Smokovec, Slovakia, 26-27 January 2017; pp. 144-147. (In Slovakia)

11. Kausrud, K.; Okland, B.; Skarpaas, O.; Gregoire, J.C.; Erbilgin, N.; Stenseth, N.C. Population dynamics in changing environments: The case of an eruptive forest pest species. Biol. Rev. 2012, 87, 34-51. [CrossRef]

12. Grégoire, J.C.; Evans, H.F. Damage and control of BAWBILT organisms-An overview. In Bark and Wood Boring Insects in Living Trees in Europe, a Synthesis; Lieutier, F., Day, K.R., Battisti, A., Grégoire, J.C., Evans, H., Eds.; Springer: Dordrecht, The Netherlands, 2009; pp. 19-37.

13. Holuša, J.; Hlásny, T.; Modlinger, R.; Lukášová, K.; Kula, E. Felled trap trees as the traditional method for bark beetle control: Can the trapping performance be increased? For. Ecol. Manag. 2017, 404, 165-173. [CrossRef]

14. Schnaider, Z.; Sierpiński, Z. Z biologii kornika zrosłozębnego (Ips duplicatus Sahlb.) (From the biology of Ips duplicatus). Roczn. Nauk. Leśn. 1955, 13, 59-68.

15. Grodzki, W. Możliwości kontroli liczebności populacji kornika zrosłozębnego Ips duplicatus C.R. Sahlb. na południu Polski. Sylwan 1997, 11, 25-36.

16. Szabla, K. Instrukcja Ochrony Lasu, cz. I, III, IV, t. I; PGL Lasy Państwowe: Bedoń, Poland, 2012; pp. 1-124.

17. Franz, J. Neues zur Bekämpfung des Buchdruckers (Ips typographus L.). Anz. Schädl. 1948, 21, 2-8. [CrossRef]

18. Prell, H. Kampf dem Fichtenborkenkäfer; Neumann: Radebeul, Germany; Berlin, Germany, 1951.

19. Chararas, C. L'influence des conditions climatiques sur l'évolution des scolytidae. Ann. Éc. Eaux Univ. Nancy 1959, 16, 135-167.

20. Švihra, P. Über die Wirksamkeit von mit eigenen Ästen zugedeckten Fangbäumen. Les. Čas. 1968, 41, 363-374.

21. Kula, E.; Šotola, V. Lýkožrout smrkový na neodvětvených a odvětvených smrkových lapácích. Zpr. Les. Výzk. 2017, 62, 42-49.

22. Pfeffer, A. Kůrovec lýkožrout smrkový a boj proti němu. In Lesnická Knihovna 12; SZN: Praha, Czech Republic, $1952 ;$ p. 45.

23. Zumr, V. Lýkožrout Smrkový—Biologie Prevence a Metody Boje; Matice lesnická: Písek, Czech Republic, $1995 ;$ p. 131.

24. Lubojacký, J.; Liška, J.; Knížek, M. Atraktivita stromových lapáků pro lýkožrouta severského, Ips duplicatus Sahlberg (Coleoptera: Curculionidae). Zpr. Les. Výzk. 2018, 63, 48-52.

25. Holuša, J.; Grodzki, W.; Lukášová, K. Porównanie skuteczności dyspenserów feromonowych ID Ecolure, Pheagr IDU i Duplodor na kornika zrosłozębnego (Ips duplicatus). Sylwan 2010, 154, 363-370.

26. Mrkva, R.; Vala, V. Lýkožrout severský: Obrana proti významnému invaznímu škůdci. Les. Prace 2009, 88, 78-80.

27. Knížek, M.; Liška, J.; Modlinger, R. Zpravodaj Ochrany Lesa. Supplementum: Výskyt Lesních Škodlivých Činiteli̊ v Roce 2016 a Jejich Očekávaný Stav v Roce 2017; Výzkumný Ústav Lesního Hospodářství a Myslivosti, v. v. i.: Strnady, Czech Republic, 2017 ; p. 68.

28. Knížek, M.; Liška, J. Zpravodaj Ochrany Lesa. Supplementum: Výskyt Lesních Škodlivých Činitelu v Roce 2017 a Jejich Očekávaný Stav v Roce 2018; Výzkumný Ústav Lesního Hospodářství a Myslivosti, v. v. i.: Strnady, Czech Republic, 2018; p. 72.

29. Knížek, M.; Liška, J. Zpravodaj Ochrany Lesa. Supplementum: Výskyt Lesních Škodlivých Činiteli̊ v Roce 2018 a Jejich Očekávaný Stav v Roce 2019; Výzkumný Ústav Lesního Hospodářství a Myslivosti. v. v. i.: Strnady, Czech Republic, 2019 ; p. 74.

30. Olenici, N.; Duduman, M.L.; Olenici, V.; Bouriaud, O.; Tomescu, R.; Rotariu, C. The first outbreak of Ips duplicatus in Romania. In Working Party 7.03.10 Methodology of Forest Insect and Disease Survey in Central Europe, Proceedings of the 10th Workshop, 20-23 September 2010; Delb, H., Pontuali, S., Eds.; Fakultät für Forst- und Umweltwissenschaften der Albert-Ludwigs-Universität Freiburg and Forstliche Versuchs- und Forschungsanstalt (FVA) Baden-Württemberg: Freiburg, Germany, 2011; Volume 89, pp. 135-140.

31. Schlyter, F.; Anderbrant, O. Competition and niche separation between two bark beetles: Existence and mechanisms. Oikos 1993, 68, 437-447. [CrossRef]

32. Pfeffer, A.; Knížek, M. Expanze lýkožrouta Ips duplicatus (Sahlb.) ze severské tajgy. Zpr. Ochr. Lesa 1995, 8-11.

33. Bakke, A. Aggregation pheromone in the bark beetle Ips duplicatus (Sahlberg). Nor. J. Entomol. 1975, 22, 67-69.

34. Byers, J.A.; Schlyter, F.; Birgersson, G.; Francke, W. E-Myrcenol In Ips duplicatus: An aggregation pheromone component new for bark beetles. Experientia 1990, 46, 1209-1211. [CrossRef]

35. Holuša, J.; Zahradník, P.; Knížek, M.; Drápela, K. Seasonal flight activity of the double-spined spruce bark beetle Ips duplicatus (Coleoptera, Curculionidae, Scolytinae) in Silesia (Czech Republic). Biologia 2003, 58, 935-941. 
36. Mrkva, R. Nové poznatky o bionomii, ekologii a hubení lykožrouta severského. Les. Prace 1995, 74, 5-7.

37. Schroeder, L.M.; Weslien, J.; Lindelöw, Å.; Lindhe, A. Attacks by bark- and wood-boring Coleoptera on mechanically created high stumps of Norway spruce in the two years following cutting. For. Ecol. Manag. 1999, 123, 21-30. [CrossRef]

38. Holuša, J.; Liška, J. Hypotéza hynutí smrkových porostů ve Slezsku (Česká republika). Zpr. Les. Výz. 2002, 47, 9-15.

39. Erbilgin, N.; Krokene, P.; Kvamme, T.; Christiansen, E. A host monoterpene influences Ips typographus (Coleoptera: Curculionidae, Scolytinae) responses to its aggregation pheromone. Agric. For. Entomol. 2007, 9, 135-140. [CrossRef]

40. Franklin, A.J.; Debruyne, C.; Grégoire, J.C. Recapture of Ips typographus L. (Col., Scolytidae) with attractants of low release rates: Localized dispersion and environmental influences. Agric. For. Entomol. 2000, 2, 259-270. [CrossRef]

41. Kandasamy, D.; Gershenzon, J.; Andersson, M.N.; Hammerbacher, A. Volatile organic compounds infuence the interaction of the Eurasian spruce bark beetle (Ips typographus) with its fungal symbionts. ISME J. 2009, 13, 1788-1800. [CrossRef]

42. Raffa, K.F.; Andersson, M.N.; Schlyter, F. Host selection by bark beetles: Playing the odds in a high-stakes game. In Advances in Insect Physiology; Blomquist, G., Tittinger, C., Eds.; Academic Press: Cambridge, UK, 2016; Volume 50, pp. 1-74.

43. Schlyter, F.; Birgersson, G. Forest Beetles. In Pheromones of Non-Lepidopteran Insects Associated with Agricultural Plants; Hardie, J., Minks, A.K., Eds.; CAB International: Walingford, UK, 1999; pp. 113-148.

44. Zhang, Q.H.; Schlyter, F. Olfactory recognition and behavioural avoidance of angiosperm nonhost volatiles by conifer-inhabiting bark beetles. Agric. For. Entomol. 2004, 6, 1-19. [CrossRef]

45. Rudinsky, J.A. Ecology of Scolytidae. Annu. Rev. Entomol. 1962, 7, 327-348. [CrossRef]

46. Wood, D. The role of pheromones, kairomones, and allomones in the host selection and colonization behavior of bark beetles. Annu. Rev. Entomol. 1982, 27, 411-446. [CrossRef]

47. Blomquist, G.J.; Figueroa-Teran, R.; Aw, M.; Song, M.; Gorzalsky, A.; Abbot, M.L.; Chang, E.; Tittiger, C. Pheromone production in bark beetles. Insect. Biochem. Mol. Biol. 2010, 40, 699-712. [CrossRef]

48. Rudinsky, J.A.; Novak, V.; Svihra, P. Pheromone and terpene attraction in the bark beetle Ips typographus L. Experientia 1971, 27, 161-162. [CrossRef]

49. Baier, P.; Bader, R.; Rosner, S. Monoterpene content and monoterpene emission of Norway spruce (Picea abies Karst.) bark in relation to primary attraction of bark beetles (Col., Scolytidae). In Proceedings of the Physiology and Genetics of Tree-Phytophage Interactions International Symposium, Gujan, France, 31 August-5 September 1997; Lieutier, F., Mattson, W.J., Wagner, M.R., Eds.; Institut National de la Recherche Agronomiqu: Paris, France, 1999; pp. 249-259.

50. Byers, J.A. Wind-aided dispersal of simulated bark beetles fying through forests. Ecol. Model. 2000, 125, 231-243. [CrossRef]

51. Duduman, M.L. Field response of the northern spruce bark beetle Ips duplicatus (Sahlberg) (Coleoptera: Curculionidae, Scolytinae) to different combinations of synthetic pheromone with (-)- $\alpha$-pinene and (+)-limonene. Agric. For. Entomol 2014, 16, 102-109. [CrossRef]

52. Chen, G.; Zhang, Q.-H.; Wang, Y.; Liu, G.-T.; Zhou, X.; Niu, J.; Schlyter, F. Catching Ips duplicatus (Sahlberg) (Coleoptera: Scolytidae) with pheromone-baited traps: Optimal trap type, colour, height and distance to infestation. Pest Manag. Sci. 2009, 66, 213-219. [CrossRef]

53. Boutelje, J. On the anatomical structure, moisture content, density, shrinkage, and resin content of the wood in and around knots in Swedish pine (Pinus silvestris L.), and in Swedish spruce (Picea abies Karst.). Sven. Papperstidn. 1966, 69, 1-10.

54. Kimland, B.; Norin, T. Wood extractives of common spruce, Picea abies (L.) Karts. Sven. Papperstidn. 1972, 75, 403-409.

55. Uçar, G.; Balaban, M.; Usta, M. Volatile needle and wood extracts of oriental spruce Picea orientalis (L.) Link. Flavour Fragr. J. 2003, 18, 368-375. [CrossRef]

56. Nisula, L. Wood Extractives in Conifers: A Study of Stemwood and Knots of Industrially Important Species; Åbo Akademi University Press: Turku, Finland, 2018.

57. Führer, E.; Wiener, L.; Hausmann, B. Dynamik von Terpen-Mustern und Borkenkäfer- befall an Fangbaum-Fichten unterschiedlichen Kronen-zustandes. Entomol. Gen. 1992, 17, 207-218. [CrossRef]

58. Hietz, P.; Baier, P. Tree temperatures, volatile organic emissions, and primary attraction of bark beetles. Phyton. Ann. Rei. Bot. A. $2005,45,341$.

59. Santos, A.M.; Vasconcelos, T.; Mateus, E.; Farrall, M.H.; Gomes Da Silva, M.D.; Paiva, M.R.; Branco, M. Characterization of the volatile fraction emitted by phloems of four pinus species by solid-phase microextraction and gas chromatography-mass spectrometry. J. Chromatogr. 2006, 1105, 191-198. [CrossRef]

60. Schlyter, F.; Birgersson, G.; Byers, J.A.; Bakke, A. The aggregation pheromone of Ips duplicatus and its role in competitive interactions with I. typographus (Coleoptera: Scolytidae). Chemoecology 1992, 3, 103-112. [CrossRef]

61. Birgersson, G.; Schlyter, F.; Löfqvist, J.; Bergström, G. Quantitative variation of pheromone components in the spruce bark beetle Ips typographus from diferent attack phases. J. Chem. Ecol. 1984, 10, 1029-1055. [CrossRef]

62. Kohnle, U.; Vité, J.P.; Baader, E.J.; Meyer, H.; Francke, W. Chirality of ipsdienol and ipsenol indicates a frass pheromone system in the spruce engraver, Ips typographus. Naturwissenschaften 1991, 78, 136-138. [CrossRef]

63. Schlyter, S. Aggregation pheromone system in the spruce bark beetle Ips typographus. Ph.D. Thesis, Department Animal Ecology, University of Lund, Lund, Sweden, 1985.

64. Bakke, A.; Fröyen, P.; Skatteböl, L. Field response to a new pheromonal compound isolated from Ips typographus. Naturwissenschaften 1977, 64, 98-99. [CrossRef] 
65. Schlyter, F.; Anderbrant, O. Mass attack of trees by Ips typographus induced by sex-specific pheromone: A model of attack dynamics author(s). Holarct. Ecol. 1989, 12, 415-426. [CrossRef]

66. Mulock, P.; Christiansen, E. The threshold of successful attack by Ips typographus on Picea abies: A field experiment. For. Ecol. Manag. 1986, 14, 125-132. [CrossRef]

67. Kretschmer, K. The effect of carrion smell on the catching-efficiency of spruce bark beetle traps. Anz. Schädl. Pflanzenschutz Umweltschutz 1990, 63, 46-48. [CrossRef] 